\title{
ANALISIS PENGARUH DIMENSI BUDAYA TERHADAP NIAT MELAKUKAN WHISTLEBLOWING PERBANDINGAN ANTARA MAHASISWA DAN ENGINEER
}

\author{
Dessy Finandari dan Titis Wijayanto \\ Program Studi Pascasarjana Tenik Indusri \\ Universitas Gadjah Mada Yogyakarta \\ Email: Dessyfinandari@gmail.com
}

\begin{abstract}
This study aims to investigate the differences between engineering students and engineers on whistleblowing intentions, the effect of cultural dimensions on whistleblowing intentions, and the effect of ethnic differences on whistleblowing intentions. Each respondent was faced with three cases: a case involving a superior, a case involving a colleague, and an unknown case who was responsible. Each respondent is asked to provide an assessment related to the seriousness of cases, responsibilities and intentions to conduct whistleblowing internally or externally. Result indicate that students have intention to do internal whistleblowing higher than engineer. The lower the power distance, the higher the internal whistleblowing intention. The higher collectivism and long-term orientation, the higher the internal whistleblowing intention. Significant ethnic differences in intent to conduct whistleblowing are found in internal whistleblowing for unknown cases, and external whistleblowing in cases involving superiors.
\end{abstract}

Keywords: Cultural Dimensions; Engineer; Engineering Studen; Whistleblowing Intention

\begin{abstract}
ABSTRAK
Tulisan ini bertujuan untuk menyelidiki perbedaan antara mahasiswa dan engineer terhadap niat melakukan whistleblowing, pengaruh dimensi budaya terhadap niat melakukan whistleblowing, dan pengaruh perbedaan suku bangsa terhadap niat melakukan whistleblowing. Setiap responden dihadapkan pada tiga kasus: kasus yang melibatkan atasan, kasus yang melibatkan rekan kerja, dan kasus dimana engineer mengetahui adanya kesalahan yang tidak diketahui siapa penanggungjawabnya. Setiap responden diminta memberi penilaian terkait tingkat keseriusan kasus, tanggung jawab serta niat untuk melakukan whistleblowing secara internal ataupun eksternal. Hasil uji menunjukkan mahasiswa memiliki niat melakukan internal whistleblowing lebih tinggi dibandingkan engineer. Semakin rendah power distance akan semakin tinggi niat untuk melakukan internal whistleblowing. Semakin tinggi collectivism dan long-term orientation akan semakin tinggi niat untuk melakukan internal whistleblowing. Perbedaan signifikan suku bangsa terhadap niat melakukan whistleblowing ditemukan pada internal whistleblowing untuk kasus yang tidak diketahui siapa penanggung jawab kesalahan, dan external whistleblowing pada kasus yang melibatkan atasan.
\end{abstract}

Kata kunci: Dimensi budaya; Engineer; Mahasiswa; Whistleblowing intention 


\section{PENGANTAR}

Selama beberapa tahun terakhir, istilah whistleblowing dan whistleblower menjadi semakin akrab ditelinga kita. Istilah whistleblowing merujuk pada tindakan pelaporan yang dilakukan oleh pekerja atau mantan pekerja suatu organisasi kepada media, kekuasaan internal atau eksternal mengenai pelanggaran, tindakan yang bertentangan dengan hukum, dan tidak etis yang terjadi dilingkungan kerja, sedangkan istilah whistleblower adalah sebutan yang diberikan kepada individu yang melakukan tindakan whistleblowing (Dalimunther, 2015). Penelitian tentang perilaku whistleblowing telah mencoba untuk menjawab pertanyaan mengapa seorang karyawan akan melakukan whistleblowing atau tidak. Sebagian besar peelitian berfokus pada empat faktor umum, yaitu faktor organisasional, faktor individual, faktor situasional,dan faktor demografis (Ahmad, 2011). Keputusan untuk mengambil tindakan dapat dipengaruhi oleh banyak faktor, dan salah satunya adalah faktor budaya. Budaya adalah nilai-nilai, keyakinan-keyakinan, aturan-aturan, dan norma-norma yuang melingkupi suatu kelompok masyarahat yang akan mempengaruhi sikap dan tindakan individu dalam masyarakat tersebut. Pengaruh budaya sangat alami dan otomatis sehingga pengaruhnya terhadap perilaku seringkali diterima begitu saja.

Penelitian lintas negara yang memiliki budaya berbeda untuk menyelidiki pengaruhnya pada niat melakukan whistleblowing telah dilakukan sebelumnya. Penelitian yang dilakukan di Indonesia juga telah banyak dilakukan. Akan tetapi, penelitian-penelitian tersebut menggunakan budaya nasional untuk mempelajari karakter individu. Ketika budaya dijabarkan pada tingkat nasional (misal collectivism), apakah seorang individu akan memiliki orientasi budaya yang sama atau tidak dengan budaya nasional haruslah dipertimbangkan. Pertimbangan ini lebih nyata saat suatu negara terdiri dari populasi yang beragam dengan latar belakang budaya yang berbeda.
Engineering adalah sebuah bidang yang dalam banyak hal menyangkut keselamatan banyak orang dan lingkungan. Seorang engineer harus berpegang pada analisis teknis yang akurat, meskipun harus menentang kebijakan perusahaan. Jika perusahaan tidak mengikuti rekomendasi dari engineer, secara etika engineer wajib untuk melaporkannya kepada pihak yang berwajib. Hal ini disebut sebagai whistleblowing, dan sering menjadi dilema bagi seorang engineer. Penelitianpenelitian sebelumnya menunjukkan masih kurangnya penelitian mengenai whistleblowing dengan mengambil subyek profesi engineer. Selain untuk memahami ruang lingkup dilema etika yang dihadapi oleh seorang engineer, adalah penting untuk melengkapi seorang engineer professional sebuah alat yang tepat untuk menghadapi situasi tersebut. Salah satu cara untuk mencapainya adalah dengan mengintegrasikan whistleblowing ke dalam kurikulum pendidikan seorang engineer. Untuk itu, perlu untuk diketahui apakah seorang engineer dan mahasiswa memiliki keinginan untuk mengambil tindakan ketika dihadapkan dengan sebuah kegiatan tidak wajar ataupun kcurangan yang terjadi dalam ruang lingkup organisasi atau perusahaannya. Untuk itu dalam penelitian ini akan menggunakan responden mahasiswa dan engineer untuk membandingkan kesediaan antar responden dalam melakukan whistleblowing.

Kajian pustaka Studi mengenai whistleblowing sebelumnya telah banyak digunakan pada beberapa subyek, diantaranya untuk eksternal auditor (Brennan dan Kelly, 2007), internal auditor (Ahmad, 2011), manajer (Keenan, 2002), polisi (Rothwell dan Baldwin, 2007), dan fisioterapis (Mansbach, 2011). Di Indonesia sendiri, beberapa penelitan mengenai whistleblwoing telah dilakukan oleh beberapa peneliti, diantaranya Banda (2012), Septiani (2013), dan Dalimunthe (2015). Penelitian mengenai whistleblowing yang mengambil bidang engineering masih relatif sedikit. Satu penelitian yang berhasil ditemukan adalah penelitian yang dilakukan oleh Keil dkk (2010). Penelitian tersebut menggunakan responden mahasiswa Manajemen Informasi / IT di 
negara Amerika Tenggara. Hasil penelitian menunjukkan bahwa faktor reporting channel pada perusahaan dan dampak pelanggaran terhadap masyarakat luas menjadi faktor seorang karyawan untuk melakukan tindakan whistleblowing.

Faktor budaya oleh beberapa peneliti juga telah dijadikan salah satu variable penelitian untuk menyelidiki pengaruhnya terhadap niat melakukan whistleblowing, antara lain dilakukan oleh Tavakoli dkk (2003), MacNab dkk (2007), Park (2008), Oktem (2012), dan Hwang (2013). Dari penelitian-penelitian sebelumnya, terlihat belum ada penelitian yang secara khusus dilakukan pada subyek dalam bidang engineering, dengan memperhatikan faktor budaya sebagai salah satu faktor yang mempengaruhi tingkah laku manusia dalam mengambil sebuah keputusan. Penelitian sebelumnya yang menggunakan dimensi budaya Hofstede lebih banyak digunakan untuk membandingkan budaya pada dua atau lebih negara yang memiliki dimensi budaya berbeda. Penelitian kali ini akan dilakukan di Indonesia, menggunakan dimensi budaya Hofstede pada tingkat individu, untuk mengetahui apakah efek budaya terhadap tingkah laku individu berpengaruh dalam kecenderungan untuk melakukan tindakan whistleblowing.

\section{Metode}

Subyek pada penelitian ini terdiri dari lima puluh lima orang engineer dan enam puluh lima orang mahasiswa. Responden dalam kelompok engineer dalam penelitian ini adalah seorang sarjana teknik, yang bekerja dalam bidang engineering dengan pengalaman kerja minimal satu tahun, sedangkan responden mahasiswa adalah mahasiswa teknik yang masuk pada tahun 2013 ke atas. Penelitian ini menggunakan kuesioner CVSCALE yang berisi pertanyaan-pertanyaan yang digunakan untuk mengukur dimensi-dimensi budaya Hofstede pada tingkat individu yang diadaptasi dari kuesioner yang dibuat oleh Yoo dkk (2001). Kuesioner kedua merupakan kuesioner dilema etika, berisi kasus-kasus yang menggambarkan dilema etika yang mungkin muncul dalam dunia kerja terutama dalam bidang engineering. Kuesioner dilema etika yang digunakan dalam penelitian ini terdiri dari tiga kasus, kasus pertama merupakan kasus yang berhubungan dengan atasan, kasus kedua merupakan kasus yang melibatkan rekan kerja, dan kasus ketiga merupakan kasus unknown. Kasus pertama dan kedua diadopsi dari dilema etika yang dikembangkan oleh Schultz (1995), sedangkan kasus ketiga merupakan adopsi dari kasus dilema etika yang dikembangkan oleh Keil (2010).

Untuk mengetahui perbedaan dimensi budaya dan whistleblowing intention pada responden akan digunakan uji independent $t$-test. Untuk mengetahui perbedaan dimensi budaya antar suku akan digunakan analisis Multivariat ANOVA. Untuk mengetahui korelasi antara dimensi budaya dan whistleblowing intention akan digunakan uji korelasi Pearson Product Moment.

\section{HASIL DAN PEMBAHASAN}

Hasil penelitian menunjukkan terdapat perbedaan dimensi budaya yang signifikan antar responden yaitu pada dimensi power distance, collectivism, long term orientation, dan masculinity (Gambar 1). Mahasiswa memiliki dimensi power distance yang lebih rendah dibandingkan engineer, sedangkan dimensi collectivism, long term orientation, dan masculinity mahasiswa lebih tinggi daripada engineer.

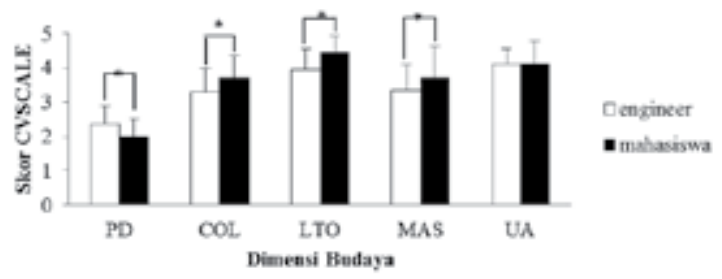

Gambar 1.

Perbedaan Dimensi Budaya antara Mahasiswa dan Engineer ( ${ }^{*}$ menunjukkan perbedaan signifikan pada $p<0,05$ )

Terdapat perbedaan siginifakan antara mahasiswa dan engineer dalam menilai 
tanggung jawab untuk melaporkan kasus, mahasiswa untuk melaporkan kasus lebih tinggi dibandingkan engineer untuk semua kasus yang digunakan. Perbedaan signifikan pada tingkatkeseriusan kasus hanya ditemukan pada kasus kedua, mahasiswa menilai tingkat keseriusan kasus yang melibatkan rekan kerja lebih tinggi dibandingkan engineer. Perbedaan tersebut bisa dilihat pada Gambar 2.
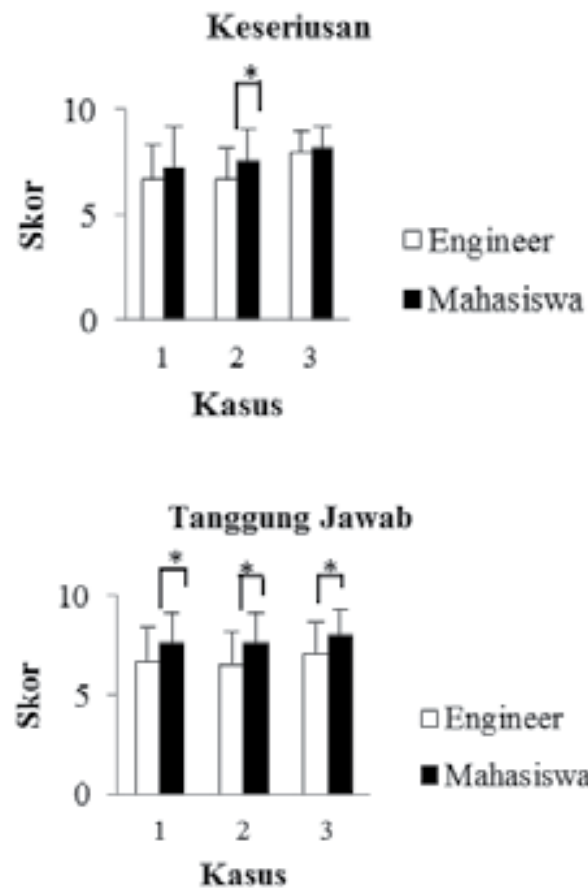

Gambar 2.

Perbedaan Tingkat Keseriusan dan Tanggung Jawab

Terdapat perbedaan signifikan terhadap niat untuk melakukan internal whistleblowing antara responden mahasiswa dan engineer, mahasiswa memiliki niat yang lebih besar dibandingkan engineer (Gambar 3). Hasil uji korelasi menunjukkan adanya korelasi signifikan positif antara tingkat keseriusan dan tanggung jawab terhadap internal whistleblowing. Hal itu berarti semakin tinggi keseriusan pelanggaran dan tanggung jawab untuk melaporkan maka akan semakin tinggi pula niat untuk melakukan internal whistleblowing.
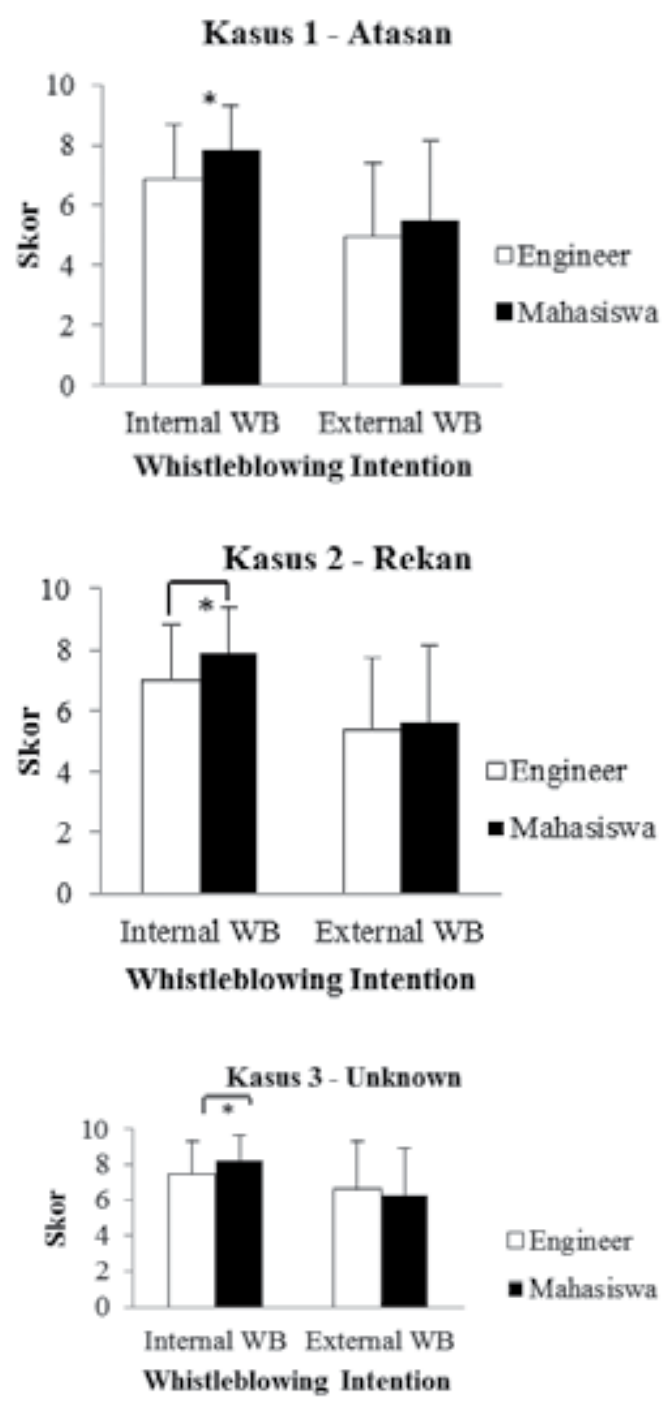

Gambar 3.

Perbedaan Niat Melakukan Whistleblowing

Mayoritas responden terbagi menjadi tiga suku, yaitu suku Jawa, Minang, dan Batak. Dari lima dimensi budaya, hanya dimensi collectivism dan masculinity yang memiliki nilai signifikan $<0,05$. Gambar 4 menunjukkan untuk dimensi collectivism, terdapat perbedaan antara suku Batak dengan suku Jawa dan Minang, sedangkan untuk dimensi masculinity perbedaan terdapat pada suku Jawa dengan suku Batak dan Minang. Hasil uji kemudian menemukan perbedaan signifikan antar suku terhadap niat melakukan whistleblowing terdapat pada internal whistleblowing intention kasus tiga yang tidak diketahui penanggungjawabnya, 
dan external whislteblowing intention kasus satu yang melibatkan atasan.

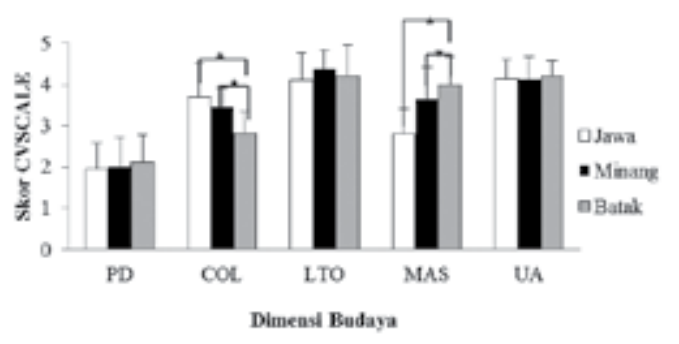

Gambar 4.

Perbedaan Dimensi Budaya antara Suku (* menunjukkan perbedaan signifikan pada $\mathrm{p}<0,05$ )

Untuk mengetahui pengaruh dimensi budaya terhadap whistleblowing intention, penelitian ini menggunakan tiga contoh kasus, kasus pertama merupakan kasus engineer berhadapan dengan kelalaian yang dilakukan oleh atasan, kasus kedua merupakan kasus engineer mengetahui adanya kecurangan yang dilakukan oleh rekan kerja, dan kasus ketiga engineer mengetahui adanya kesalahan yang tidak diketahui siapa penanggungjawabnya. Penelitian ini menemukan adanya perbedaan signifikan antara mahasiswa dan engineer pada niat melakukan internal whistleblowing pada semua contoh kasus yang digunakan, mahasiswa memiliki kecenderungan yang lebih tinggi dibandingkan engineer. Adanya perbedaan tersebut dapat disebabkan oleh beberapa kemungkinan, antara lain engineer menyadari adanya resiko yang akan diterima ketika melakukan tindakan pelaporan.

Pada kuesioner dilema etika, sebelum responden memberi penilaian mengenai tingkat kemungkinan untuk melapor, responden diminta untuk memberikan penilaian mengenai tingkat keseriusan kasus dan tingkat tanggung jawab responden untuk melaporkan kasus. Hasil uji menunjukkan adanya perbedaan signifikan antara mahasiswa dan engineer. Perbedaan signifikan tingkat keseriusan terlihat pada kasus kedua yang melibatkan rekan, dan perbedaan signifikan tingkat tanggung jawab ditemukan pada semua kasus. Hasil tersebut menunjukkan mahasiswa memandang pelanggaran yang dilakukan oleh rekan kerja lebih serius dibandingkan engineer.
Perbedaan pada tingkat tanggung jawab antara mahasiswa dan engineer ditemukan pada semua kasus, yang menunjukkan mahasiswa memiliki rasa tanggung jawab untuk melaporkan pelanggaran dibandingkan engineer, baik ketika pelanggaran melibatkan atasan, rekan kerja, maupun ketika pelanggaran belum diketahui siapa yang bertangung jawab.

Jika merujuk pada hasil uji korelasi, tingkat keseriusan dan tanggung jawab berkorelasi signifikan secara positif dengan niat melakukan internal whistleblowing yang berarti semakin tinggi keseriusan pelanggaran dan tanggung jawab untuk melaporkan maka akan semakin tinggi pula niat untuk melakukan internal whistleblowing. Namun analisis sebelumnya menghasilkan perbedaan signifikan antara mahasiswa dan engineer pada tingkat keseriusan hanya pada kasus kedua, sedangkan pada tingkat tanggung jawab terdapat perbedaan signifikan pada semua kasus. Idealis yang tinggi pada mahasiswa dan belum memasuki kondisi pekerjaan yang nyata kemungkinan menghasilkan adanya perbedaan yang signifikan tersebut. Didukung dengan fakta bahwa mahasiwa lebih sering melakukan demo atau protes dibandingkan para pekerja.

Hasil penelitian juga menunjukkan terdapat perbedaan dimensi budaya antara engineer dan mahasiswa, perbedaan signifikan ditemukan pada dimensi power distance, collctivism, long-term orientation, dan masculinity. Perbedaan dimensi budaya antara mahasiswa dan engineer dapat disebabkan oleh beberapa kemungkinan, antara lain budaya organisasi yang berbeda antara lingkungan kampus dan lingkungan kerja, idealisme yang tinggi pada mahasiswa, dan ritme kerja yang tinggi pada lingkungan kerja nyata sehingga budaya individualisme pada engineer meningkat.

Berdasarkan uji korelasi, diketahui untuk semua kasus, dimensi power distance berkorelasi signifikan secara negatif dengan niat melakukan internal whistleblowing. Hal itu berarti semakin tinggi nilai power distance seseorang maka akan semakin rendah niat untuk melakukan whistleblowing internal. Hasil 
penelitian ini senada dengan penelitian yang dilakukan oleh Tavakoli dkk (2003). Damesyani (2013) mengatakan bahwa salah satu ungkapan yang mengindikasikan tingginya nilai power distance adalah "Asal Bapak Senang", sebuah ungkapan yang digunakan ketika seseorang melakukan tindakan untuk menyenangkan hati dan memperoleh simpati dari atasan. Dalam budaya power distance, posisi atasan memiliki tingkat kekuasaan yang lebih tinggi dan orang dengan kedudukan yang lebih tinggi harus selalu dipatuhi serta ditaati. Ketimpangan dalam pendistribusian kekuasaan pada dimensi power distance yang tinggi, menyebabkan individu-individu ini akan tunduk kepada posisi otoritas dan ragu untuk mengambil tindakan sendiri. Rasa ragu ini juga termasuk saat menemukan terjadinya sebuah kecurangan ataupun tindakan tidak wajar dalam organisasi atau perusahaan mereka, sehingga niat untuk melaporkannya atau melakukan tindakan whistleblowing menjadi rendah.

Penelitian ini menemukan adanya korelasi positif yang signifikan antara dimensi collectivism dan niat melakukan whistleblowing internal pada semua kasus. Hal ini menunjukkan bahwa seseorang dengan sifat collectivism yang tinggi akan memiliki niat untuk melakukan tindakan whistleblowing yang tinggi pula. Hasil penelitian ini senada dengan penelitian yang dilakukan oleh Tavakoli dkk (2003), yang menyebutkan bahwa budaya collectivism menganggap bahwa individu merupakan bagian kecil dari sebuah kelompok yang lebih besar dan karena itu mendorong perilaku untuk bertindak selalu mendahulukan kepentingan kelompok dibandingkan kepentingan pribadi, termasuk untuk melakukan tindakan whistleblowing. Dimensi collectivism lebih mungkin untuk melakukan whistleblowing karena mereka cenderung untuk peduli pada kesejahteraan bersama dibandingkan kebutuhan pribadi mereka sendiri, dengan mengabaikan akibat yang muncul akibat pelaporan tersebut.

Korelasi positif juga ditemukan antara dimensi long-term orientation terhadap niat melakukan internal whistleblowing, yang menunjukkan bahwa semakin seseorang memikirkan orientasi jangka panjangnya, maka akan semakin tinggi pula kecenderungan untuk memiliki niat melakukan whistleblowing. Hasil penelitian ini senada dengan hasil penelitian yang dilakukan oleh Zhuang (2002), yang menyebutkan bahwa Cina yang merupakan masyarakat dengan orientasi jangka panjang (longt-term orientation) memiliki kecenderungan lebih besar untuk melakukan tindakan whistleblowing. Individu dengan budaya long-term orientation yang berorientasi pada masa depan memiliki kekahawatiran mengenai konsekuensi jangka panjang dari adanya kesalahan ataupun pelanggaran yang dilakukan dalam perusahaan atau organisasi, sehingga lebih cenderung untuk terlibat dalam tindakan whistleblowing.

Pada dimensi masculinity, ditemukan korelasi signifikan yang positif terhadap niat melakukan tindakan internal whistleblowing. Hal ini berarti semakin seseorang memiliki kecenderungan bersifat masculin akan semakin tinggi pula niat untuk melakukan tindakan whistleblowing. Hasil penelitian senada dengan penelitian yang dilakukan oleh Tavakoli dkk (2003) yang menemukan bahwa masyarakat dengan budaya masculin memiliki kecenderungan yang kuat untuk melakukan whistleblowing. Pada dimensi masculinity, individu akan lebih bersedia menghadapi konflik secara terbuka, dan menganggap sebuah pelanggaran sebagai sesuatu yang serius. Namun, uji korelasi menunjukkan dimensi ini berkorelasi hanya ada kasus kedua yang melibatkan rekan kerja, dimensi ini tidak menunjukkan adanya korelasi pada kasus pertama dan kasus ketiga

Uncertainty avoidance adalah suatu tingkatan dimana seseorang merasa terancam oleh situasi yang tidak menentu atau yang tidak dipahami, semakin tinggi nilai uncertainty avoidance mengindikasikan seseorang yang lebih menyukai keadaan dengan kepastian, memiliki kecenderungan rule orientation, dan lebih suka dengan adanya aktivitas yang lebih terstruktur. Hasil penelitian menunjukkan terdapat korelasi positif terhadap niat melakukan whistleblowing internal. Hasil penelitian 
ini senada dengan penelitian yang dilakukan oleh MacNab dkk (2007) di Kanada, yaitu bahwa dimensi uncertainty avoidance memiliki korelasi positif dengan intention whistleblowing. Seseorang dengan uncertainty avoidance yang tinggi selalu ingin menjaga stabilitas struktur, dan sebuah pelanggaran merupakan salah satu tindakan yang menyebabkan kestabilan tersebut menjadi goyah,sehingga akan menuntun untuk melakukan tindakan whistleblowing. Akan tetapi, uji korelasi menunjukkan dimensi ini berkorelasi hanya ada kasus pertama yang melibatkan atasan dan kasus ketiga yang unknown. Pada kasus kedua yang melibatkan rekan kerja, dimensi ini tidak menunjukkan adanya korelasi.

Penelitian ini juga meneliti perbedaan dimensi budaya antar suku dan pengaruhnya terhadap niat melakukan whistleblowing. Hasil uji menyebutkan dari tiga suku mayoritas yaitu suku Jawa, Minang dan Batak, perbedaan signifikan hanya terdapat pada dimensi collectivism dan masculinity. Perbedaan signifikan antar suku terhadap niat melakukan whislteblowing hanya ditemukan pada internal whistleblowing kasus ketiga dan external whislteblowing kasus pertama pada kasus pertama untuk external whistleblowing. Hasil penelitian ini sedikit berbeda dengan hasil penelitian yang dilakukan oleh Yenlisa (2016) yang dilakukan di tiga provinsi di Indonesia, yaitu Provinsi D.I. Yogyakarta, DKI Jakarta dan Sumatera Utara. Hasil penelitian tersebut menunjukkan bahwa pada Provinsi D.I. Yogyakarta dan Provinsi Sumatera Utara terdapat perbedaan dalam lima dimensi kultur. Kedua provinsi tersebut memiliki suku mayoritas yang berbeda, yaitu suku Jawa dan Batak. Selanjutnya penelitian tersebut menemukan bahwa kultur pada masingmasing provinsi memberikan hasil yang berbeda terhadap niat melakukan tindakan whistleblowing, khususnya antara provinsi DI Yogyakarta dan Sumatera Utara. Perbedaan hasil dapat disebabkan perbedaan sampel yang digunakan. Pada penelitian ini analisis dimensi budaya dilakukan fokus pada suku tertentu, sedangkan pada penelitian sebelumnya analisis dimensi budaya dilakukan pada lingkup provinsi dimana dalam satu provinsi terdiri dari berbagai macam suku.

\section{SIMPULAN}

Kesimpulan yang dihasilkan dari penelitian ini adalah bahwa dimensi budaya pada tingkat individu memiliki pengaruh terhadap niat melakukan whistleblowing, terutama melakukan internal whistleblowing. Semakin tinggi nilai budaya power distance, maka niat melakukan internal whistleblowing akan semakin rendah. Sebaliknya, semakin tinggi nilai dimensi collectivism, long-term orientation, masculinity, dan uncertainty avoidance, maka akan semakin tinggi pula niat untuk melakukan internal whistleblowing. Terdapat perbedaan budaya yang signifikan antara mahasiswa dan engineer, yaitu pada dimensi power distance, collectivism, longterm orientation, dan masculinity. Mahasiswa memiliki niat melakukan internal whistleblowing yang lebih tinggi dibandingkan engineer. Perbedaan signifikan suku bangsa terhadap niat melakukan whistleblowing hanya terdapat internal whistleblowing kasus ketiga dan external whistleblowing kasus pertama. Secara umum bisa dikatakan bahwa suku bangsa tidak memiliki pengaruh terhadap niat whistleblowing. Terdapat perbedaan yang signifikan antara mahasiswa dan engineer terhadap niat melakukan internal whistleblowing.

\section{DAFTAR PUSTAKA}

Ahmad, S. A., 2011, Internal Auditor and Internal Whistleblowing: A Study of Organisational, Individula, Situational and Demographic Factors, Tesis, Edith Cowan University, Western Australia.

Armia, C., 2002, Pengaruh Budaya terhadap Efektivitas Organisasi: Dimensi Budaya Hofstede, JAAI Volume 6 No.1

Banda, F.L., 2012, Pengaruh Penalaran Moral, Sikap, Norma, Subyektif dan Persepsi Kontrol Perilaku Terhadap Whistleblowing Intention, 
Tesis, Universitas Gadjah Mada, Yogyakarta.

Bertens, K, 1993, Etika, Gramedia Pustaka Utama, Jakarta

Brennan, N., and Kelly, J., 2007, A study of whistleblowing among trainee auditors, The British Accounting Review Vol.39 pg 61-87.

Bouville, M., 2007, Whistleblowing and Morality, Journal of Business Ethics Vol.81, pg 579.

Christie, P.M.J, Kwon, I.G, Stoeberl, P.A, and Baumhart, R, 2003, A Cross-Cultural Comparison of Ethical Attitudes of Business Managers: India, Korea and the United States, Journal of Business Ethics Vol. 46, pg 263-287.

Damesyani, A.W., and Juneman, A., 2013, Impulsive Buying, Cultural Values Dimension, and Symbolic Meaning of Money: A Study on College Students in Indonesia's Capital City and its Surrounding, Inernational Journal of Research Studies in Psychology, Volume 2 Number 4, pg 35-52.

Dalimunthe, R.N.P., 2015, Pengaruh Penalaran Moral dan Kolektivisme Terhadap Niat Melakukan Whistleblowing (Studi Empiris pada Mahasiswa Akuntansi S1 FEB UGM), Skripsi, Universitas Gadjah Mada, Yogyakarta.

Dungan, J., Waytz, A., and Young , L., 2015, The Psychology of Whistleblowing, Current Opinion in Psychology Vol. 6, pg 129-133.

Gokce, A.T., 2013, Whistleblowing Intention of Prospective Teachers ; Education Evidence, International Education Studies Vol. 6 No.8.

Hwang, D.B.K., Chen, Y., and Staley, A.,B., 2013, A Comparative Study of the Propensity of Whistle-Blowing: Empirical Evidence from China, Taiwan, and the United States, International Journal of Accounting and Financial Reporting Vol.3 No.2.
Keenan, J.P., 2002, Whistleblowing: A Study of Managerial Differences, Employee Responsibilities and Rights Journal Vol. 14 No. 1.

Keenan, J.P, 2007, Comparing Chinese and American Managers on Whistleblowing, Employ Respons Rights Journal Vol.19, pg 85-94.

Keil,M., and Park,C., 2010, Bad news reporting on troubled IT projects: Reassessing the mediating role of responsibility in the basic whistleblowing model, The Journal of Systems and Software Vol.83, pg 2305-2316.

Layn, Y.Y., 2011, Pengaruh Komitmen Profesional, Antisipasi Sosial, Skeptisme Profesional dan Penalaran Mahasiswa Akuntansi Terhadap Whistleblowing, Tesis, Universitas Gadjah Mada, Yogyakarta.

MacNab, B., Galperin, B.L., and Lituchy, T.R., 2007, National Homogeneity vs. RegionalSpecificity: An Examination of the Canadian Cultural Mosaic and Whistle-Blowing, Canadian Journal of Regional Science (Summer, 2007), pg 293-312

Mansbach, A., Melzer, I., and Bachner, Y.G., 2011, Blowing the Whistle to Protect A Patient: A Compariso Between Physiotherapy Students and Physiotherapsits, Chartered Society of Physiotherapy Vol.98, pg 307-312.

National Society Profesional Engineers, Code of Ethics for Engineers, 2007, Virginia

Oktem, M.K., and Shahbzi, G., 2012, Attitudes Toward Different Forms of Whistleblowing in Turkey and Iran, Middle-East Journal of Scientific Research Vol.12 (7), pg 945-951

Park, H., Blenkisopp, J., and Oktem, M.K., 2008, Cultural orientation and attitudes towards different forms of whistleblowing: A comparison of South Korea, Turkey and the UK, Journal of Business Ethics Vol.82 (4), pg 929-939. 
Prasongsukarn, K., 2009, Validating the Cultural Value Scale (CVSCALE): A Case Study of Thailand, ABAC Journal Vol.29 No.2, pg 1-13.

Rothwell, G.R., and Baldwin, N, 2007, Whistleblowing and the Code of Silence in Police Agencies, Crime and Delinquency Journal Vol. 54, pg 605632.

Septianti, W., 2013, Pengaruh Faktor Organisasional, Individual, Situasional, dan Demografis Terhadap Niat Melakukan Whistleblowing Internal, Tesis, Universitas Gadjah Mada, Yogyakarta.

Schultz, J.J, Johnson, D.A, Morris, D, and Dyrnes, S, 1993, An Investigation of the Reporting of Questionable Acts in an International Setting, Journal of Accountung Research Vol. 31, pg 75103.

Shuriye, A.O, 2011, Understanding Engineering Ethics, IIUM Engineering Journal, Vol. 12, No. 5.

Sihombing, S.o dan Pongtuluran, F.D., 2011, Pengindentifikasian DimensiDimensi Budaya Indonesia: Pengembangan Skala dan Validasi, International Conference Political Economy of Trade Liberalization. Universitas Brawijaya, Malang, 24-25 November.

Soehardi, 2002, Nilai-nilai Tradisi Lisan dalam Budaya Jawa, Jurnal Budaya, Sastra dan Bahasa, Vol.4 No.3, hal.4.

Suryono, E., 2014, Pengaruh Sikap dan Norma Subyektif terhadap Intensi Pegawai Negeri Sipil untuk Mengadukan
Pelanggaran, Skripsi, Universitas Diponegoro, Semarang.

Suoarlan, P., 2003, Bhinneka Tunggal Ika: Keanekaragaman Sukubangsa atau Kebudayaan, Antropolgi Indonesia, Vol.72.

Tavakoli, A.A., Keenan, J.P., and CrnjakKaranovic, B., 2003, Culture and Whistleblowing An Empirical Study of Croatian and United States Managers Utilizing Hofstede's Cultural Dimension, Journal of Business Ethics Vol.43,pg 49-64.

Widiastuti, 2013, Analisis SWOT Keberagaman Budaya Indonesa, Jurnal Ilmiah Widya, Volume 1 Nomor 1.

Wrigt, P.H, 2002, Pengantar Engineering, Jakarta, Erlangga

Yenlisa, 2016, Pengaruh Kultur dan Tipe Kepribadian Terhadap Niat Melakukan Whistleblowing (Studi Empiris pada Mahasiswa S1 Akuntansi di Provinsi DI Yogyakarta, DKI Jakarta, dan Sumatera Utara), Skripsi, Universitas Gadjah Mada.

Yoo, B., Donthu, N., and Lenartowicz, T., 2011, Measuring Hofstede's Five Dimensions of Cultural Values at the Individual Level: Development and Validation of CVSCALE, Journal of International Consumer Marketing Vol. 23, pg 193-210

Zhuang, J., 2002, Whistleblowing and Peer Reporting: A Cross Cultural Comparison of Canadians and Chinese, Faculty od Management, University of Lethbridge, Lethbridge, Alberta, Canada 